\title{
Enterobacter sakazakii: A New Species of "Enterobacteriaceae" Isolated from Clinical Specimens
}

\author{
J. J. FARMER III, M. A. ASBURY, F. W. HICKMAN, DON J. BRENNER, AND THE \\ ENTEROBACTERIACEAE STUDY GROUP $\dagger$
}

Enteric Section, Center for Disease Control, Atlanta, Georgia 30333

\begin{abstract}
Enterobacter sakazakii is the name proposed for the organism previously known as "yellow-pigmented Enterobacter cloacae." The type strain (holotype) of this species is ATCC 29544. The proposed change in the classification of this organism is based on differences between $E$. cloacae and E. sakazakii in deoxyribonucleic acid (DNA)-DNA hybridization, biochemical reactions, pigment production, and antibiotic susceptibility. By DNA hybridization, E. sakazakii was about $50 \%$ related to $E$. cloacae, Citrobacter diversus ("Citrobacter intermedius" biotype b), and "Citrobacter amalonaticus" ("Citrobacter intermedius" biotype a). The new species was placed in Enterobacter rather than Citrobacter because of its closer phenotypic and DNA similarity to $E$. cloacae, the type species of the genus Enterobacter, and because it was only $41 \%$ related by DNA hybridization to Citrobacter freundii, the type species of Citrobacter. E. sakazakii had biochemical reactions very similar to those of $E$. cloacae but was D-sorbitol negative and positive for extracellular deoxyribonuclease at 2 to 7 days and produced yellow-pigmented colonies. $E$. sakazakii had larger zones of inhibition around ampicillin and cephalothin antibiotic disks, which also helps to differentiate it from $E$. cloacae. E. sakazakii grew on the nonselective (but differential) plating media commonly used in enteric bacteriology, but its plating efficiency was reduced on more inhibitory enteric plating media. It has been isolated from human clinical specimens such as sputum, feces, and wounds, where it is probably only a colonizer and not clinically significant. However, it is also a documented, although rare, cause of neonatal meningitis. Other sources have included food, a physician's stethoscope, and an uninoculated blood culture bottle.
\end{abstract}

As new knowledge accumulates, changes in the classification of members of the family " $E n$ terobacteriaceae" (scientific names in quotation marks were not included in the Approved Lists [24]) become necessary $(4,8,9,12,19,21,23)$. A few of these changes have involved consolidation of organisms previously thought to be distinct species. The four Shigella species and Escherichia coli although phenotypically distinct, are closely related by other criteria and could be considered as belonging to the same species (7). Similarly, Klebsiella ozaenae and Klebsiella rhinoscleromatis are comprised of host-adapted strains ("patho-bio-sero-geogroups") which belong in the same species with Klebsiella pneumoniae (11). Other changes have involved "splitting" rather than "lumping." New species previously thought to be biogroups (biotypes or biovars) within a recognized species have been proposed recently. Examples include Klebsiella oxytoca, previously thought to be an indole-positive biogroup of $K$. pneumoniae (19); Proteus

†The participants and their affiliations are listed in the Acknowledgments at the end of this paper. myxofaciens (8), which was not considered a distinct species; and "Yersinia frederiksenii" and "Y. intermedia," which were thought to be biogroups of $Y$. enterocolitica (5). In this paper, we describe another new species previously thought to be a biogroup of an existing species. We argue that the organism previously referred to as a "yellow-pigmented Enterobacter cloacae" really belongs to a new species, and we propose Enterobacter sakazakii sp. nov. as its scientific name.

Oxidase-negative bacteria which ferment $D$ glucose and produce a yellow pigment have had a confusing history and many different names. Today, it is impossible to identify most of these strains described in the early literature. Many of the yellow strains were originally placed in $\mathbf{B a}$ cillus, Bacterium, Pseudomonas, Xanthomonas, Chromobacterium, Flavobacterium, Erwinia, or Pectobacterium, or were simply called "yellow-pigmented coliforms" or "yellow paracolons." Unless thorough phenotypic descriptions are given in the literature, it is impossible to tell whether these organisms are $E$. sakazakii or any other currently recognized species. There 
are, however, two published reports describing cases of serious neonatal meningitis which were almost certainly caused by E. sakazakii. In 1958 (published in 1961), Urmenyi and Franklin (27) investigated two fatal cases of generalized sepsis and meningitis at Osterhills Hospital (St. Albans City Hospital) in England. The two cases occurred within 1 week of each other, and at autopsy, strains of an organism described as "a pigmented organism belonging to the cloacae group A" (a "yellow-pigmented Enterobacter cloacae" in today's terminology) were isolated and confirmed at the Manchester Public Health Laboratory by $\mathbf{M}$. T. Parker. Isolates were from brain tissue, cerebrospinal fluid, and other autopsy specimens. No definite conclusions were drawn on the source of the organism, but the two neonates may have shared the same incubator, although 1 week apart. The authors speculated that an aerosol of the organism may have come from the incubator and caused the infections; however, the incubator, when tested "several days" after the deaths, was negative for the infecting organism. Another case of meningitis due to "yellow-pigmented $E$. cloacae" was described in 1965 by Jøker et al. (20), who were at the city and county hospital of Odense, Denmark. The organism was isolated from spinal fluid of a baby on days 6,8 , and 11 after birth. The meningitis cleared after antibiotic treatment (which included chloramphenicol and ampicillin), and the infant survived. In contrast to the previous report, these authors gave a complete description of the organism which caused the meningitis, including its reactions for 39 biochemical tests commonly used in enteric bacteriology. They also wrote to M. T. Parker (at the Central Public Health Laboratory, London) and asked him to compare their organism with the two strains isolated by Urmenyi and Franklin. The English strains differed from the Danish one only in gas production from glycerol, inositol, and starch and in malonate utilization. The description given by Jøker et al. for all three strains conforms perfectly to that given below for $E$. sakazakii, considering the different biogroups given in Tables 1, 2, and 3. These three strains and similar ones have been studied in several laboratories over the last 20 years (12, 14). The conclusion has always been that they are "yellow-pigmented strains of Enterobacter cloacae" because their phenotypic properties are similar to those of E. cloacae. Edwards and Ewing (14) state that they received six or eight such cultures over 15 years and that without exception they were typical strains of $E$. cloacae in every respect except pigment production. Thus, it appeared that $E$. cloacae might be analogous to Serratia marcescens because some strains produce pigment whereas many do not.
The first evidence that "yellow-pigmented $E$. cloacae" should not be included in the species $E$. cloacae came in 1972 (published in 1974) from Don J. Brenner's laboratory, then at Walter Reed Army Institute of Research (4). Nonpigmented strains of $E$. cloacae were highly related by deoxyribonucleic acid (DNA)-DNA hybridization, but the "yellow-pigmented $E$. cloacae" strains were less than $50 \%$ related to the nonpigmented strains. This finding was later substantiated with additional yellow strains (26, Fig. 1). In this paper we show that $E$. sakazakii is different from $E$. cloacae in its biochemical reactions, antibiotic susceptibility, and DNA hybridization.

\section{MATERIALS AND METHODS}

General. Unless exceptions are given, the following statements hold throughout this paper: all experiments were done in the Enteric Section, Center for Disease Control (CDC); the temperature of incubation was $36 \pm 1^{\circ} \mathrm{C}$; water refers to glass-distilled water; commercial media were used whenever possible (the terms "from individual ingredients" or "was made with" appear if a commercial medium was not used); media were sterilized in an autoclave at $121^{\circ} \mathrm{C}$ for 15 min; optical density was measured in a Bausch and Lomb Spectronic 20 spectrophotometer at $650 \mathrm{~nm}$ in 13- by $100-\mathrm{mm}$ disposable glass tubes; filter sterilization was through a $0.22-\mu \mathrm{m}$ nitrocellulose filter; refrigeration was at a temperature of $5 \pm 1^{\circ} \mathrm{C}$; all results are based on cultures picked twice from a single isolated colony each time; and the term "antibiotic" refers to true antibiotics and to synthetic antimicrobial agents.

Nomenclature. Nomenclature is from the eighth edition of Bergey's Manual of Determinative Bacteriology (12), with the following exceptions (9). We use Enterobacter agglomerans instead of the threenamed species in the "Herbicola group" of Erwinia (Erwinia herbicola, Erwinia stewartii, and Erwinia uredovora ); Citrobacter diversus instead of " $C$. intermedius" biotype b (another synonym is Citrobacter koseri); and "Citrobacter amalonaticus" instead of "C. intermedius" biotype a. Enteric group 1 (also called "Alma group 1") is an unnamed group of yellowpigmented, Enterobacter-like strains which are homogenous in their biochemical reactions and by DNADNA hybridization. They have been described by Leete (J. K. Leete, Doctor of Public Health Dissertation, School of Public Health, University of North Carolina, Chapel Hill, N.C., 1977; J. K. Leete, A. C. McWhorter, and D. J. Brenner, Abstr. Annu. Meet. Am. Soc. Microbiol. 1977, C155, p. 61).

Media. Commercial media were from Difco (Difco Laboratories, Detroit, Mich.), BBL (BBL Microbiology Systems, Cockeysville, Md.), or Oxoid (Oxoid Ltd., London, England). Special media were also used. For example, 0.2 carbon broth was made with $1 \mathrm{~g}$ of trypticase peptone (BBL Microbiology Systems) and $1 \mathrm{~g}$ of yeast extract per $1,000 \mathrm{ml}$ of water; final $\mathrm{pH}$ was 7.0. Phage broth (CDC medium 1473) was made with $15 \mathrm{~g}$ of nutrient broth, $7 \mathrm{~g}$ of sodium chloride, and $1,000 \mathrm{ml}$ of water. Organic carbon assimilation base (CDC medium 7751) was made with $5 \mathrm{~g}$ of sodium chloride, $0.2 \mathrm{~g}$ of magnesium sulfate, $1 \mathrm{~g}$ of 
$\left(\mathrm{NH}_{4}\right) \mathrm{H}_{2} \mathrm{PO}_{4}, 1 \mathrm{~g}$ of $\mathrm{K}_{2} \mathrm{HPO}_{4}, 0.08 \mathrm{~g}$ of bromothymol blue, and $1,000 \mathrm{ml}$ of water ( $\mathrm{pH} 6.8$ ). XLD base-three additions was made by autoclaving $\mathrm{XL}$ agar base (Difco), cooling it to $50^{\circ} \mathrm{C}$, and adding $20 \mathrm{ml}$ of filtersterilized supplement 1 ( $34 \mathrm{~g}$ of sodium thiosulfate and $4 \mathrm{~g}$ of ferric ammonium citrate in $100 \mathrm{ml}$ of water), and $25 \mathrm{ml}$ of filter-sterilized supplement $2(10 \mathrm{~g}$ of sodium desoxycholate in $100 \mathrm{ml}$ of water); final volume was $1,000 \mathrm{ml}$. Other special media are described under the section on biochemical tests.

Bacterial strains. Fifty-seven strains subsequently identified as members of $E$. sakazakii were submitted to the Enteric Section, CDC, from 1970 to 1977. Many of the strains received from 1970 to 1975 were sent for identification from primary hospital laboratories and were usually sent through a regional or state health department. The 57 strains are described in Table 1. (We now have over 100 strains. Occasionally, data based on this larger collection are mentioned if they appear to be particularly useful.) Strains 33 to 57 were submitted from investigators in laboratories in the United States and Canada who are members of the Enterobacteriaceae Study Group and who had agreed to search for strains of E. sakazakii. The clinical significance of $E$. sakazakii as judged for strains received from 39 hospital laboratories is given briefly. Our overall study began in 1972 , when we had only a few isolates of $E$. sakazakii, and continued to 1977. Unless otherwise stated, the number of strains studied for each characteristic was 57 ; however, some tests were done with fewer than 57 strains. A computer printout giving all properties determined for each strain can be obtained upon request to one of us (J.J.F.). Twenty-four consecutive isolates of $E$. cloacae received from 1970 to 1975 were taken from the culture collection, Enteric Section, CDC, and used for comparison with $E$. sakazakii. All tests for the other taxa mentioned in Table 2 were done previously and were taken from the publications or the computer records of the Enteric Section.

Because yellow pigment production is stronger below $36^{\circ} \mathrm{C}$, all strains of $E$. sakazakii were streaked onto Trypticase soy agar and incubated at $25^{\circ} \mathrm{C}$ for 2 to 5 days. A Trypticase soy agar stock culture was made of the whole culture (picked in an area of confluent growth), and a second stock was made of the wrinkled, leathery colony type (marked A in Fig. 2b) if this colony type was present. These stocks were sealed with a rubber stopper and stored in the dark at room temperature $\left(17\right.$ to $\left.30^{\circ} \mathrm{C}\right)$. All of the stock cultures (some are now 8 years old) have remained viable without transfer. Different colony types on plates streaked for isolation were recorded as the strains were received. Stock cultures that had been picked from a single colony were later restreaked, and different colony types were recorded.

DNA-DNA hybridization. The genetic relatedness of strains was determined by DNA-DNA hybridization on hydroxyapatite. The methods used have been extensively described by Brenner et al. (4-8), and the original papers should be consulted for technical details too lengthy to repeat here. Closely or highly related strains (that is, belonging to the same species) are usually taken to have relative binding of $70 \%$ or more (occasionally down to $60 \%$ ). Strains not related at the species level usually have values of from 0 to $60 \%$. All renaturation experiments were at $60^{\circ} \mathrm{C}$.
G+C content of DNA. The percentage of guanine plus cytosine $(\mathrm{G}+\mathrm{C})$ was determined by cesium chloride centrifugation (21) in the laboratory of Manley Mandel, M. D. Anderson Hospital, Houston, Tex., from unsheared DNA furnished by D. J. Brenner. Values were determined twice in the presence of reference DNAs from bacteriophage $2 \mathrm{C}$ (density $=1.742$ $\mathrm{g} / \mathrm{cm}^{3}$ ) and $E$. coli K-12 (density $=1.710 \mathrm{~g} / \mathrm{cm}^{3}$ ). Because of the variables in the technique, the results of $\mathrm{G}+\mathrm{C}$ content were rounded to two significant figures.

Staining. Hucker's modification was used for the Gram strain (24), and decolorization was done for 30 $\mathrm{s}$ in $95 \%$ ethanol. Flagella strains were done in the Special Bacteriology Section, CDC, by W. A. Clark, with a simplified Leifson stain (13).

Nutrition: requirements for vitamins or amino acids. We noted that all of the $E$. sakazakii cultures had grown on Simmons citrate agar, which has citrate as the sole source of carbon (except for the agar and any impurities it may contain) and energy. Organic carbon assimilation base (CDC medium 7751), with $1 \%$ glucose, was inoculated with about $10^{4}$ cells of each of the 57 strains grown in Trypticase soy broth. Serial transfers $\left(10^{4}\right.$ cells each time) were made (after $48 \mathrm{~h}$ of incubation) seven times in this medium to dilute any nutrients from the original inoculum.

Biochemical tests. The methods used were generally those described by Edwards and Ewing $(14,18)$. Unless otherwise stated (Table 2), all tests were held for 7 days before being discarded as negative. A description of the tests follows.

Indole production was measured at 24 and $48 \mathrm{~h}$ by adding $0.5 \mathrm{ml}$ of Kovacs reagent ( $10 \mathrm{~g}$ of paradimethylaminobenzaldehyde, $50 \mathrm{ml}$ of $12 \mathrm{~N}$ hydrochloric acid, and $150 \mathrm{ml}$ of isoamyl alcohol) to 24 -h- and 48-h-old peptone water $(20 \mathrm{~g}$ of peptone [Difco], $5 \mathrm{~g}$ of sodium chloride, and $1,000 \mathrm{ml}$ of water) cultures. The methyl red test (standard method) was done only at $48 \mathrm{~h}$ by adding $0.5 \mathrm{ml}$ of indicator $(0.1 \mathrm{~g}$ of methyl red, $300 \mathrm{ml}$ of $95 \%$ ethanol) to the culture grown in $5 \mathrm{ml}$ of methyl red-Voges-Proskauer medium in a 16- by $125-\mathrm{mm}$ tube. Method 2 for the methyl red test was done by adding $0.1 \mathrm{ml}$ of methyl red indicator to a $48-\mathrm{h}$-old culture grown in $1 \mathrm{ml}$ of methyl red-Voges-Proskauer medium in a 13 - by $100-\mathrm{mm}$ tube. The Voges-Proskauer test was done at 24 and $48 \mathrm{~h}$ by adding $1 \mathrm{ml}$ of O'Meara reagent $(40 \mathrm{~g}$ of potassium hydroxide, $0.3 \mathrm{~g}$ of creatine, and $100 \mathrm{ml}$ of water; discarded after 7 days) to $1 \mathrm{ml}$ of the culture (grown in methyl redVoges-Proskauer medium) in a 100 - by $13-\mathrm{mm}$ tube.

Growth on citrate as the sole source of carbon and energy was tested on Simmons citrate agar. Growth on acetate as the sole source of carbon and energy was determined on Simmons agar base (Difco), made with $2.5 \mathrm{~g}$ of sodium acetate per $1,000 \mathrm{ml}$ of base. Growth on malonate and citrate as energy sources was determined in malonate broth and on Christensen citrate agar, respectively. A culture was defined to be malonate-positive if the $\mathrm{pH}$ changed from an initial $\mathrm{pH}$ of 6.7 to a pH of more than 7.4 (the color of the bromothymol blue indicator in the medium was compared with a series of color standards and was dark blue [15]) after 24 or $48 \mathrm{~h}$ of incubation.

Hydrogen sulfide production $\left(\mathrm{H}_{2} \mathrm{~S}\right)$ was determined in triple sugar iron agar (with an additional $5 \mathrm{~g}$ of agar added per liter of medium). Peptone iron agar was 


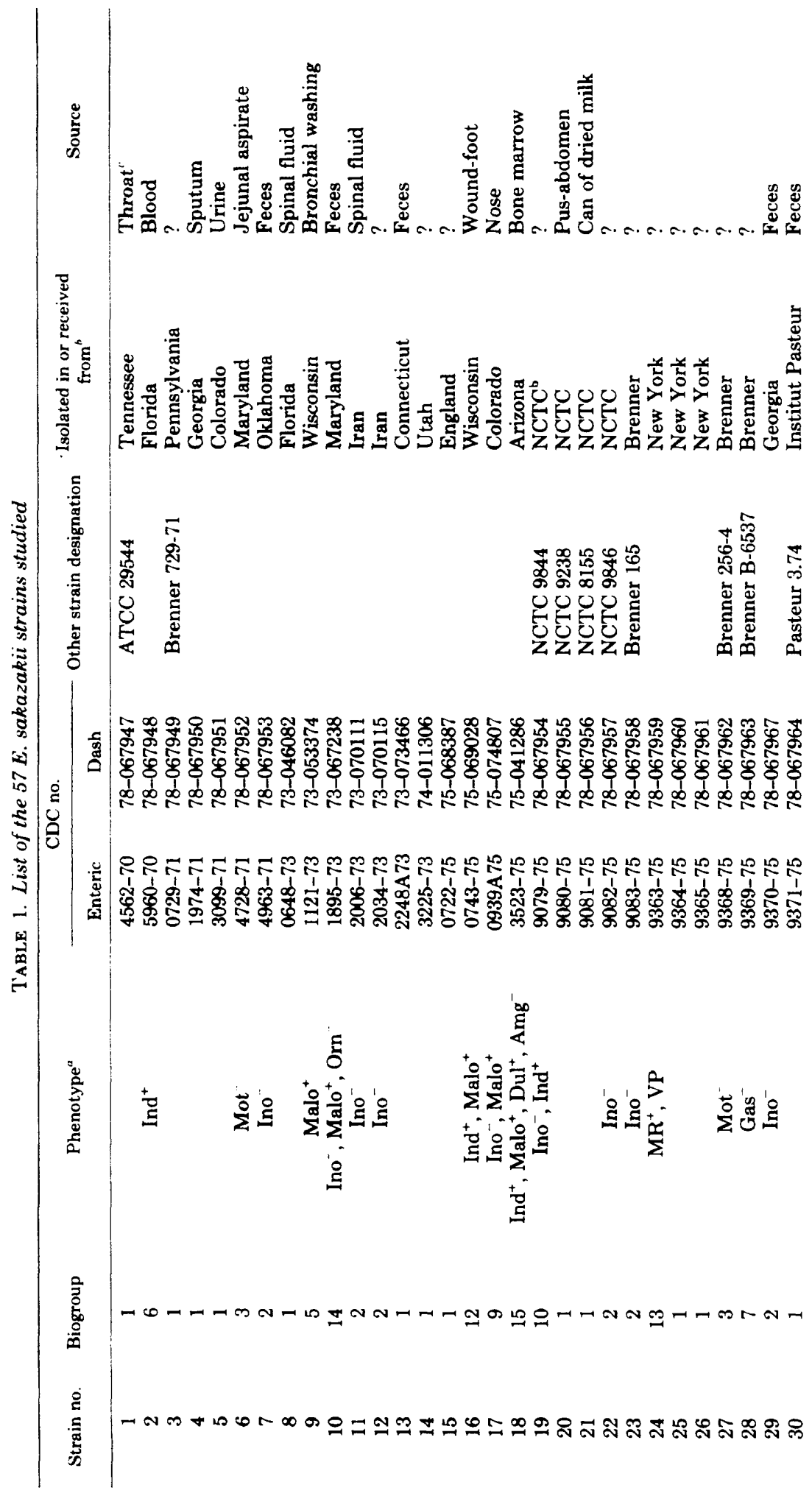




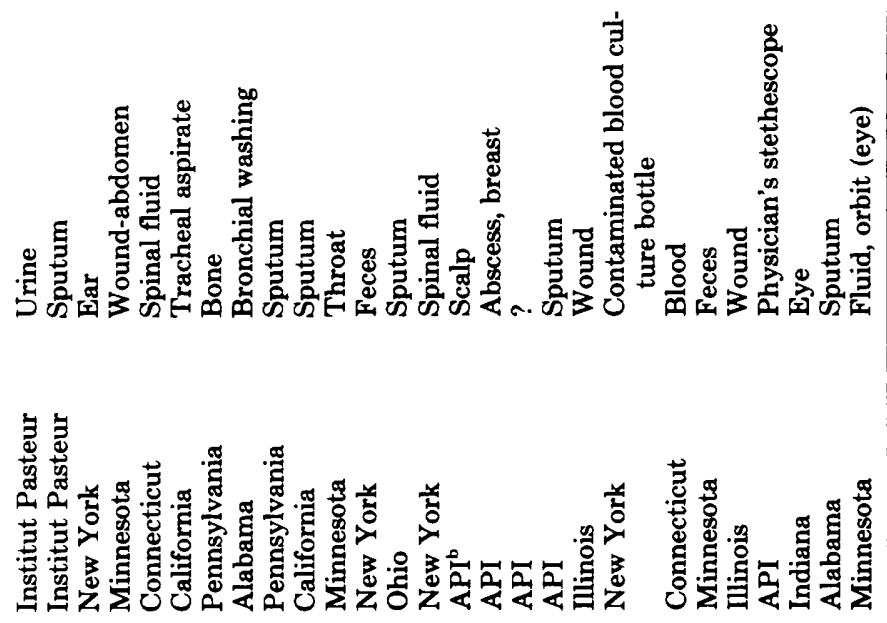

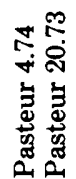

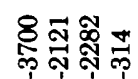

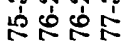

安军安

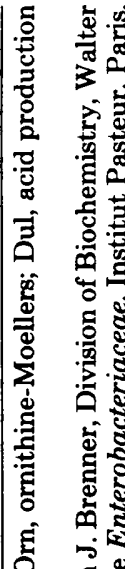

¿ิ

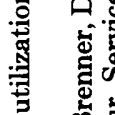

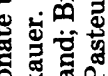

要

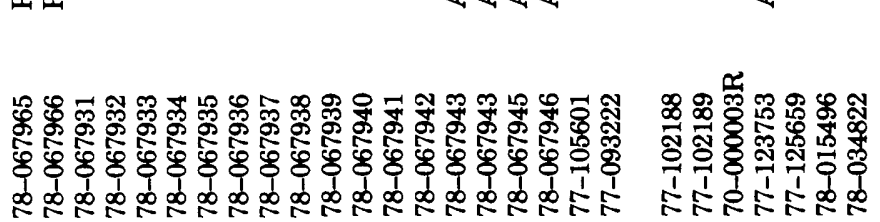

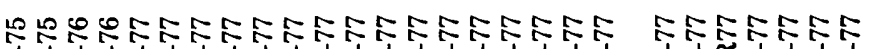

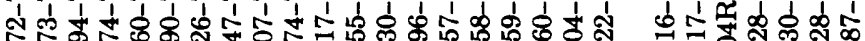

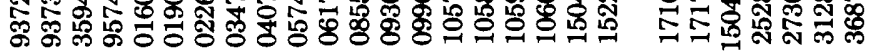

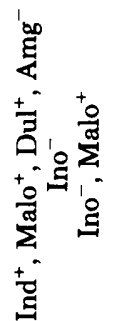

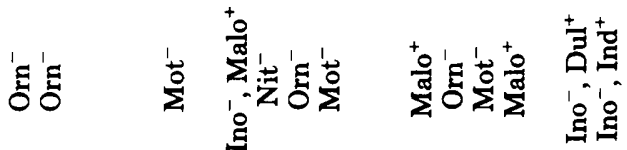

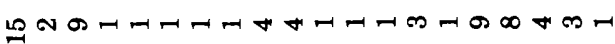

מ

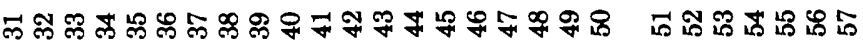


used in a slightly more sensitive test for $\mathrm{H}_{2} \mathrm{~S}$ production. Urea hydrolysis was determined on Christensen urea agar. Phenylalanine "deamination" was tested by adding $0.1 \mathrm{ml}$ of ferric chloride solution $13 \mathrm{~g}$ of ferric chloride, $100 \mathrm{ml}$ of water) to a 24-h-old culture on phenylalanine agar. The Moeller method (14) was used for lysine and ornithine "decarboxylases" and arginine "dihydrolase." The L-configuration of the amino acid was used, not the D,L-mixture. Motility was determined at 36 and $22^{\circ} \mathrm{C}$ in motility test medium. Gelatin hydrolysis was determined only at $22^{\circ} \mathrm{C}$ on nutrient gelatin. Growth in the presence of cyanide (the KCN test) was determined in a peptone basal medium made from $10 \mathrm{~g}$ of Orthana peptone (Orthana Kemish Fabrik, 350-356 Englandsuej DK-2770 Kastrup, Denmark), $5 \mathrm{~g}$ of sodium chloride, $5.64 \mathrm{~g}$ of $\mathrm{Na}_{2} \mathrm{HPO}_{4}, 0.23 \mathrm{~g}$ of $\mathrm{KH}_{2} \mathrm{PO}_{4}$, and $1,000 \mathrm{ml}$ of water; (pH adjusted to 7.6) to which $15 \mathrm{ml}$ of potassium cyanide solution ( $0.5 \mathrm{~g}$ of $\mathrm{KCN}, 100 \mathrm{ml}$ of water) had been added. (Warning: $\mathrm{KCN}$ is very poisonous; it must be handled with extreme caution.)

Acid production from carbohydrates, polyhydroxyl alcohols, and related compounds was tested in enteric fermentation base (Difco product no. C836-01) (10 g of peptone, $3 \mathrm{~g}$ of meat extract, $5 \mathrm{~g}$ of sodium chloride) to which $10 \mathrm{ml}$ of Andrade (14) indicator and $990 \mathrm{ml}$ of water were added. Andrade indicator contained 0.2 $\mathrm{g}$ of acid fuchsin, $100 \mathrm{ml}$ of water, and $16 \mathrm{ml}$ of $1 \mathrm{~N}$ $\mathrm{NaOH}$. Each fermentation tube contained a small glass insert tube (Durham tube) to detect gas production, but gas production was tabulated only for $D$ glucose. Compounds were added before the autoclaving step (10 min only), except for L-arabinose, cellobiose, lactose, maltose, L-rhamnose, sucrose, and Dxylose, which were filter-sterilized and added to the fermentation base after it had cooled. The final concentration of compounds was $0.5 \%$, except that cellobiose, D-glucose, lactose, maltose, D-mannitol, sucrose, and D-xylose had final concentrations of $1 \%$. Acid production from $i$-inositol (also called myo- or mesoinositol) was weak for many strains; a positive reaction was defined to be the lowering in $\mathrm{pH}$ from 7.2 to below 6.7 (a slightly pink color). Inositol-negative strains raised rather than lowered the $\mathrm{pH}$. Fermentation rather than oxidation of D-glucose was shown in oxidation-fermentation medium with $1 \%$ added D-glucose. After being inoculated, the tubes were sealed with 2 $\mathrm{ml}$ of sterile petrolatum to exclude oxygen. Acid production from mucate was tested in organic acid medium (made with $10 \mathrm{~g}$ of peptone, $10 \mathrm{~g}$ of sodium mucate, $0.024 \mathrm{~g}$ of bromothymol blue, $1,000 \mathrm{ml}$ of water, and $1 \mathrm{~N} \mathrm{NaOH}$ to make a final pH 8.8). Acid production from L-tartrate was tested in Jordon tartrate agar.

Lipid hydrolysis was tested on corn oil-lipase medium made with $10 \mathrm{~g}$ of peptone, $3 \mathrm{~g}$ of yeast extract, $5 \mathrm{~g}$ of sodium chloride, $5 \mathrm{ml}$ of corn oil, $20 \mathrm{~g}$ of agar, $0.067 \mathrm{~g}$ of Victoria blue, and $1,000 \mathrm{ml}$ of water. Extracellular deoxyribonuclease (DNase) was tested at 36 and $25^{\circ} \mathrm{C}$ on DNase test agar (BBL Microbiology Systems) to which $0.05 \mathrm{~g}$ of toluidine blue was added (before autoclaving) per $1,000 \mathrm{ml}$. Reduction of nitrate to nitrite was tested on nitrate reduction test medium. After the culture had grown for $24 \mathrm{~h}, 0.1 \mathrm{ml}$ of solution A $10.5 \mathrm{~g}$ of sulfanilic acid, $30 \mathrm{ml}$ of glacial acetic acid, and $120 \mathrm{ml}$ of water) and $0.1 \mathrm{ml}$ of solution B $(0.2 \mathrm{~g}$ of 5-amino-2-naphthalene sulfonic acid (also called 1,6
Cleve acid), $30 \mathrm{ml}$ of glacial acetic acid, and $120 \mathrm{ml}$ of water) were added. A pinch (about $0.01 \mathrm{~g}$ ) of zinc dust was added to negative tubes to confirm that nitrate was still present and had not been reduced. The oxidase test was done according to Kovac's method by rubbing growth from a 24-h-old Trypticase soy agar culture onto filter paper soaked (and still wet) with a $0.5 \%$ solution of tetramethyl-p-phenylene-diamine or (method 2) by flooding a 24-h-old culture grown on nutrient agar with $0.3 \mathrm{ml}$ of the reagent. The oxidase test was considered positive if a purple color developed at $10 \mathrm{~s}$ (Kovac's method) or $60 \mathrm{~s}$ (method 2). The reactions were also recorded at $60 \mathrm{~s}$ (Kovac's method) and $5 \mathrm{~min}$ (method 2) to determine weak oxidase activity. The ONPG test used was the one recommended by Negut and Hermann (22). The basal tryptose medium was made with $4 \mathrm{~g}$ of tryptose, $4 \mathrm{~g}$ of yeast extract, $5 \mathrm{~g}$ of sodium chloride, $3 \mathrm{~g}$ of agar, and $800 \mathrm{ml}$ of water. After it was autoclaved and cooled, $200 \mathrm{ml}$ of $0.1 \%$-nitrophenyl- $\beta$-D-galactopyranose (filter-sterilized) was added. Yellow pigment production was observed for cultures grown on Trypticase soy agar incubated at 36 and $25^{\circ} \mathrm{C}$. Production of catalase was determined by dropping $0.05 \mathrm{ml}$ of $3 \%$ hydrogen peroxide on 24-h-old Trypticase soy agar cultures. The hydrolysis of pectate was tested by observing the liquefaction of pectate medium (14). The clearing of precipitated L-tyrosine was determined on Trypticase soy agar to which $0.4 \% \mathrm{~L}$-tyrosine had been added.

Definition of biogroups. Table 2 shows that some tests were uniformly positive or negative for all 57 strains but that other tests had a variable percent positive. For example, $75 \%$ of the strains fermented $i$ inositol (Ino) but 25\% did not, which indicates the presence of Ino $^{+}$and Ino $^{-}$biogroups. The following tests (after $24 \mathrm{~h}$ of incubation, unless otherwise indicated) were used to define 15 biogroups (Table 3): indole production, methyl red test (method 2 at $48 \mathrm{~h}$ ), Voges-Proskauer, ornithine decarboxylase, motility, malonate utilization, gas production from D-glucose at $48 \mathrm{~h}$, and acid production from $i$-inositol $(48 \mathrm{~h})$, dulcitol, and $\alpha$-methylglucoside.

Susceptibility to antibiotics: Disk Method. The standardized single-disk method of Bauer et al. (2) was used to determine antibiotic susceptibility, and the zones of complete inhibition around the antibiotic disks (BBL Microbiology Systems) were measured. Table 4 lists the antibiotic disks used, potencies, and abbreviations. Conversion of the zone sizes into susceptible, intermediate, and resistant was based on the zone-size interpretative chart supplied with the disks.

Susceptibility to antibiotics: MICs in MuellerHinton broth. For determining minimum inhibitory concentrations (MICs), the commercial product Sensititre (made by Stewart Laboratory, London, England, purchased from GIBCO Diagnostics, Lawrence, Mass.) was used according to the manufacturer's instructions (Table 5). Strains were picked from 24-hold colonies on Trypticase soy agar plates and inoculated (about $10^{6}$ cells) into $0.5 \mathrm{ml}$ of brain heart infusion broth. They were grown for 4 to $6 \mathrm{~h}$ (to about $10^{9}$ cells per $\mathrm{ml}$ ), and a $0.001-\mathrm{ml}$ loopful was transferred to $10 \mathrm{ml}$ of Mueller-Hinton broth (GIBCO) to give about $10^{5}$ bacteria per $\mathrm{ml}$. Then, $0.05 \mathrm{ml}$ of this diluted suspension was added to each of the 96 wells of a disposable plastic microculture plate. The wells contain dehydrated antimicrobial agents, which, when 
reconstituted with $0.05 \mathrm{ml}$, give a serial twofold dilution series for each agent. Both the APO3-Urinary and APO2-Gram Negative antibiotic plates were used. This combination gave the following dilution series: ampicillin, 0.25 to $128 \mu \mathrm{g} / \mathrm{ml}$; carbenicillin, 4 to $512 \mu \mathrm{g} /$ $\mathrm{ml}$; cephalothin, 1 to $128 \mu \mathrm{g} / \mathrm{ml}$; amikacin, 0.25 to 32 $\mu \mathrm{g} / \mathrm{ml}$; gentamicin, 0.12 to $64 \mu \mathrm{g} / \mathrm{ml}$; kanamycin, 0.5 to $256 \mu \mathrm{g} / \mathrm{ml}$; tobramycin, 0.12 to $16 \mu \mathrm{g} / \mathrm{ml}$; chloramphenicol, 0.5 to $56 \mu \mathrm{g} / \mathrm{ml}$; sulfisoxazole, 0.5 to $256 \mu \mathrm{g}$ / $\mathrm{ml}$; tetracycline, 0.25 to $64 \mu \mathrm{g} / \mathrm{ml}$; nalidixic acid, 1 to $128 \mu \mathrm{g} / \mathrm{ml}$; nitrofurantoin, 2 to $256 \mu \mathrm{g} / \mathrm{ml}$; and the drug combination trimethoprim-sulfamethoxazole (in the same well), 0.25 to $32 \mu \mathrm{g} / \mathrm{ml}$ and 4.75 to $608 \mu \mathrm{g} / \mathrm{ml}$, respectively. Ten strains (numbers 33 to 42 ) were studied with this method.

Growth on plating media commonly used in enteric bacteriology. All 57 strains were tested on four general-use plating media (Table 6)-MacConkey agar (BBL Microbiology Systems), eosin methylene blue agar (Difco), deoxycholate agar (Difco), and tergitol 7 agar (Difco); three media for the selection of enteric pathogens-xylose-lysine-desoxycholate agar (XLD; BBL Microbiology Systems), XLD-three additions (Difco), and Hektoen agar (BBL Microbiology Systems); two media selective for Salmonella-brilliant green agar (Difco) and bismuth sulfite agar (Difco); and on thiosulfate-citrate-bile salts-sucrose (TCBS) agar (BBL Microbiology Systems) which is selective for Vibrio (Table 6). Media which had been refrigerated for 7 days were compared with media refrigerated overnight. Cultures which had grown for $24 \mathrm{~h}$ in 0.2 carbon broth (optical density $=0.1$ ) were diluted in phage broth to contain $10^{1}, 10^{3}, 10^{5}$, or $10^{8}$ colony-forming units per $\mathrm{ml}$, respectively. These were loaded into the multisyringe applicator described by Farmer et al. (16), and a 0.01-ml drop of each strain was simultaneously inoculated onto each of the plating media (in 150 - by $20-\mathrm{mm}$ petri dishes) and onto Trypticase soy agar. The number of visible colonies on each plating medium was compared to the number on the nonselective medium (Trypticase soy agar). The plating efficiency was then calculated by dividing the number of colonies on the plating medium by the number (at the same dilution) of colonies on Trypticase soy agar. Colonial morphology and color changes in the medium were also noted on the lowest dilution of each strain.

Lactose fermentation, the coliform concept and the fecal coliform concept. Lactose fermentation, the coliform concept, and the fecal coliform concept tests were done according to instructions in the 14th edition of Standard Methods for the Examination of Water and Wastewater (1), except that pure cultures were used (Table 7). Each tube was inoculated with $10^{3}$ to $10^{4}$ organisms grown in brain heart infusion broth (except for brilliant green bile broth and EC medium, which were inoculated with $0.001 \mathrm{ml}$ of a 48$\mathrm{h}$-old culture in lauryl tryptose broth as required in Standard Methods). The insert tubes were observed for gas formation; the tubes were gently shaken, and the presence or absence of gas bubbles was noted.

\section{RESULTS}

DNA-DNA hybridization. Figure 1 shows that by DNA-DNA hybridization the type strain of E. sakazakii was 83 to $89 \%$ related to the other strains in this species but only 31 to $49 \%$ related to strains of $E$. cloacae. This difference, and the phenotypic differences found later, form the basis of our proposal that E. sakazakii is a new species rather than a phenotypically distinct subgroup within the existing species $E$. cloacae. Table 8 gives the relatedness of $E$. sakazakii to other groups in the family "Enterobacteriaceae."

$\mathbf{G}+\mathbf{C}$ ratio. The DNAs of strains 3,23 , and 27 all had a density of 1.716 , which corresponds to a $57 \%$ content of $\mathrm{G}+\mathrm{C}$.

Name. The name Enterobacter sakazakii is here proposed in honor of the Japanese bacteriologist Riichi Sakazaki for his many contributions to our current understanding of "Enterobacteriaceae," Vibrionaceae, and enteric bacteriology. We first tried the five-syllable pronunciation of the specific epithet (sa, ka, zá ki, i). After several months there was a natural (unplanned) change to a four-syllable pronunciation (sa, ka, zá ki). Others also seem to prefer the shorter pronunciation, and we propose that the four-syllable pronunciation be used. (Editor's Note: This proposal contravenes the rules of pronunciation and thus is not endorsed by the Editor.) Common names of this organism are "the Urmenyi and Franklin bacillus" and "yellow-pigmented Enterobacter cloacae." Other names that have been used include "yellow coliform," "pigmented cloacae A organism," and "yellow Enterobacter." Cultures from the National Collection of Type Cultures, which cultures we subsequently identified as $E$. sakazakii, had been labeled as Serratia or "Chromobacterium typhiflavum." "C. typhiflavum" is a heterogenous species and has a confusing history; thus, "typhiflavum" was rejected very early as a possible specific epithet for the organism under consideration. The name $E$. sakazakii was first used in May, 1977 at the Annual Meeting of the American Society for Microbiology, but it did not appear in the abstract (J. J. Farmer III, F. W. Hickman, and D. J. Brenner, Abstr. Annu.

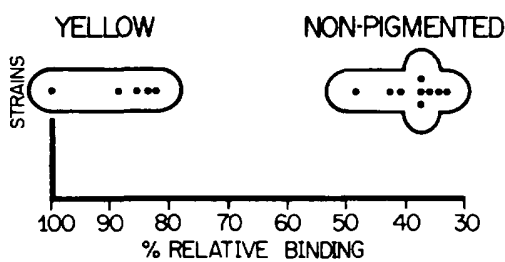

Fig. 1. Differentiation of yellow-pigmented ( $E$. sakazakii) from nonpigmented strains of $E$. cloacae by DNA-DNA hybridization. E. sakazakii strain 1 was radioactively labeled, and the other strains were tested for their relatedness at $60^{\circ} \mathrm{C}$. The values for the $E$. sakazakii strains were as follows: strain 1 (homologous) $=100 \%$, strain $3=86 \%$, strain $27=$ $84 \%$, strain $23=83 \%$, and strain $28=82 \%$. 
Meet. Am. Soc. Microbiol. 1977, C154, p. 61). It was also used in a 1977 publication from the CDC (9). However, this present paper is the first claim that undoubtedly meets all of the criteria for valid publication under the Bacteriological Code, 1975 Revision.

Type strain. American Type Culture Collection (ATCC) strain 29544 (deposited at the ATCC by J.J.F.) is the halotype strain. It was originally labeled CDC 4562-70 (78-067947) and was isolated in 1970 from the throat culture of a patient in Tennessee whose illness had been diagnosed as whooping cough. Biochemical reactions of the type strain are given in Table 2. Two colony types of the type strain have consistently been present; they are identical in their phenotypic properties, except that one is negative and the other is positive in our standard for the methyl red test (but both are negative by method 2).

Morphology of cells. E. sakazakii is a gramnegative rod about $3 \mu \mathrm{m}$ long and $1 \mu \mathrm{m}$ wide (Fig. 2); the cells are motile and peritrichous. Spore formation has never been observed.

Nutrition and growth. E. sakazakii grew on D-glucose (through seven serial transfers) and citrate without any other added source of carbon or energy, so there was no obvious requirement for vitamins, amino acids, or other organic growth factors. All 57 strains grew at 25, 36, and $45^{\circ} \mathrm{C} ; 50$ strains grew at $47^{\circ} \mathrm{C}$, but none grew at 4 or $50^{\circ} \mathrm{C}$. It is a facultative anaerobe, since it grew both aerobically and anaerobically (in an anaerobic glove box with all oxygen removed).

Colonies on peptone media. All strains of E. sakazakii grew rapidly on Trypticase soy agar at $36^{\circ} \mathrm{C}$ and formed colonies 2 to $3 \mathrm{~mm}$ in diameter after $24 \mathrm{~h}$. At $25^{\circ} \mathrm{C}$ the colonies were generally 1 to $1.5 \mathrm{~mm}$ at $24 \mathrm{~h}$ and 2 to $3 \mathrm{~mm}$ at $48 \mathrm{~h}$. Colonies were bright yellow after $48 \mathrm{~h}$ at $25^{\circ} \mathrm{C}$, but pigment production was greatly diminished at $36^{\circ} \mathrm{C}$. Many of the freshly isolated strains had two or more different colony types when they were first streaked for purity. Colony type A (Fig. 3) was either dry or mucoid, crenated (notched or scalloped), and rubbery when touched with a loop (very little growth was removed, and the colony snapped back when touched). In addition to colony type A, many of the strains also contained colony type B (Fig. 3), which was a typical smooth colony, easily removed with a wire loop. Stock cultures made from clones of colony type A soon dissociated into colony type B. Some strains also produced a smooth colony which was barely yellow and difficult to score as positive or negative for yellow-pigment production. With experience a (typical) strain can be tentatively identified as $E$. sakazakii by its appearance on Trypticase soy agar after incubation at $25^{\circ} \mathrm{C}$ for $48 \mathrm{~h}$. This identification must be confirmed by biochemical reactions (Table 1 ).

Growth in broth. Growth was rapid (density change of $10^{4}$ to $10^{9} / \mathrm{ml}$ overnight) in Trypticase soy broth, and a large amount of sediment was produced by all strains (Fig. 4). This sediment (observed in a wet mount at a magnification of $440 \times$ ) appeared to contain clumped cells and amorphous masses (perhaps of clumped cells) which are similar or identical to the symplasmata produced by "Erwinia herbicola-Enterobacter agglomerans" and illustrated in Fig. 1 of the paper by Gilardi and Bottone (17).

Biochemical results. Table 2 gives the biochemical reactions for all 57 strains, including the type strain. Each test result which differed from the expected pattern was repeated. Most results require no comment; a few do. The test for phenylalanine deaminase was difficult to score as positive or negative because most of the slants turned slightly green 30 to $60 \mathrm{~s}$ after the ferric chloride test reagent was added. Some readers in the Enteric Section scored this as "-(weak)," but others scored it as "+(weak)." We arbitrarily tabulated this as a variable test with $50 \%$ of the strains positive, but different strains usually had the same faint green color. None of the strains hydrolyzed gelatin within 2 days, but $49 \%$ had at 7 days, and $100 \%$ had at 21 days. As stated previously, yellow pigment production was best at $25^{\circ} \mathrm{C}$ but the DNase test was stronger at $36^{\circ} \mathrm{C}$ than at $25^{\circ} \mathrm{C}$. Although seven strains were methyl red positive with our standard test, six of these were negative when the volume of broth was reduced to $1 \mathrm{ml}$ to increase access to oxygen, a procedure which favors oxidation of acids produced during fermentation. Strain 24 was methyl red positive, Voges-Proskauer negative regardless of the test conditions, so we concluded that the acetoin pathway had been lost genetically or was not being expressed. None of the strains was oxidase positive, but at the 10-s reading a few were beginning to become a faint purple, with the color deepening at $1 \mathrm{~min}$. Many other species of "Enterobacteriaceae" also do this (a few strains even become a strong purple at $10 \mathrm{~s}$ ). All strains were catalase positive. Inositol-positive strains lowered the $\mathrm{pH}$ of the test medium, but inositolnegative strains made the medium alkaline. Strain 38 was originally recorded as ornithinenegative because the tube was yellow to colorless; however, this was a false-negative reaction because the strain had actually decolorized the indicator. The true $\mathrm{pH}$ was 6.7 , but the $\mathrm{pH}$ according to the color of the indicator was less than 6 . We have recently noted (unpublished data) that other strains of "Enterobacteriaceae" also decolorize acid-base indicators and give incorrect readings. 
TABLE 2. Biochemical reactions of 57 strains of $E$. sakazakii, including the type strain, and of the type strain of E. cloacae

\begin{tabular}{|c|c|c|c|c|c|}
\hline \multirow{2}{*}{ Test } & \multicolumn{3}{|c|}{$\begin{array}{l}\text { Cumulative } \% \text { positive for } 57 \text { strains } \\
\text { at: }\end{array}$} & \multicolumn{2}{|c|}{ Reaction $^{a}$ for type strain of: } \\
\hline & $24 \mathrm{~h}$ & $48 \mathrm{~h}$ & 7 days & $\begin{array}{l}\text { E. sakazakii ATCC } \\
29544\end{array}$ & $\begin{array}{c}\text { E. cloacae ATCC } \\
13047\end{array}$ \\
\hline Indole production & 11 & 11 & ND & - & - \\
\hline Methyl red & ND & 12 & ND & - & - \\
\hline Voges-Proskauer & 98 & 98 & ND & + & + \\
\hline Citrate, Simmons & 100 & 100 & 100 & + & + \\
\hline Hydrogen sulfide on $\mathrm{TSI}^{b}$ & 0 & 0 & 0 & - & - \\
\hline Urea, Christensen & 0 & 0 & 0 & - & - \\
\hline Phenylalanine & $50^{c}$ & ND & ND & $\left(+{ }^{w}\right)^{c}$ & - \\
\hline Lysine, Moellers & 0 & 0 & 0 & - & - \\
\hline Arginine, Moellers & 93 & 100 & 100 & + & $t^{2}$ \\
\hline Ornithine, Moellers & 91 & 91 & 91 & + & + \\
\hline Motility at $36^{\circ} \mathrm{C}$ & 91 & 91 & 91 & + & + \\
\hline Gelatin hydrolysis at $22^{\circ} \mathrm{C}$ & 0 & 0 & 45 & $+^{7}$ & - \\
\hline Growth in KCN & 84 & 100 & 100 & + & + \\
\hline Malonate utilization & 18 & 18 & 18 & - & + \\
\hline D-Glucose-acid production & 100 & 100 & 100 & + & + \\
\hline D-Glucose-gas production & 96 & 98 & 98 & + & + \\
\hline \multicolumn{6}{|l|}{ Acid production from: } \\
\hline D-Adonitol & 0 & 0 & 0 & - & - \\
\hline L-Arabinose & 100 & 100 & 100 & + & + \\
\hline D-Arabitol & 0 & 0 & 0 & - & - \\
\hline Cellobiose & 100 & 100 & 100 & + & + \\
\hline Dulcitol & 5 & 5 & 5 & - & - \\
\hline Erythritol & 0 & 0 & 0 & - & - \\
\hline Glycerol & 0 & 0 & 0 & - & $+^{3}$ \\
\hline$i$-Inositol & 75 & 75 & 75 & + & $t^{2}$ \\
\hline Lactose & 100 & 100 & 100 & + & + \\
\hline Maltose & 100 & 100 & 100 & + & + \\
\hline D-Mannitol & 100 & 100 & 100 & + & + \\
\hline D-Mannose & 100 & 100 & 100 & + & + \\
\hline Melibiose & 100 & 100 & 100 & + & + \\
\hline$\alpha$-Methyl-D-glucoside & 93 & 96 & 96 & + & + \\
\hline Raffinose & 100 & 100 & 100 & + & + \\
\hline L-Rhamnose & 100 & 100 & 100 & + & + \\
\hline Salicin & 98 & 100 & 100 & + & + \\
\hline D-Sorbitol & 0 & 0 & 0 & - & + \\
\hline Sucrose & 100 & 100 & 100 & + & + \\
\hline Trehalose & 100 & 100 & 100 & + & + \\
\hline D-Xylose & 100 & 100 & 100 & + & $+^{6}$ \\
\hline Mucate-acid production & 0 & 0 & 0 & - & - \\
\hline Tartrate, Jordan & 0 & 0 & 0 & - & - \\
\hline Esculin hydrolysis & 100 & 100 & 100 & + & $t^{2}$ \\
\hline Acetate utilization & 84 & 96 & 100 & + & + \\
\hline Citrate, Christensen & 100 & 100 & 100 & + & + \\
\hline Hydrogen sulfide on PIA & 0 & 0 & 0 & - & - \\
\hline $\mathrm{NO}_{3} \rightarrow \mathrm{NO}_{2}$ & 98 & ND & ND & + & + \\
\hline Motility at $22^{\circ} \mathrm{C}$ & 89 & 91 & 91 & + & + \\
\hline DNase at $25^{\circ} \mathrm{C}$ & 0 & 0 & 95 & $+^{5}$ & - \\
\hline DNase at $36^{\circ} \mathrm{C}$ & 2 & 9 & 100 & $+^{3}$ & - \\
\hline Lipase-corn oil & 0 & 0 & 0 & - & - \\
\hline $\mathrm{ONPG}^{d}$ & 100 & 100 & 100 & + & + \\
\hline Pectate hydrolysis & 0 & 0 & 0 & - & - \\
\hline Yellow pigment at $25^{\circ} \mathrm{C}$ & 100 & 100 & 100 & + & - \\
\hline Tyrosine clearing & 0 & 0 & 0 & - & - \\
\hline
\end{tabular}

${ }^{a}$ Symbols: - , negative at end of incubation period (see text); + , positive at $24 \mathrm{~h} ;\left(+{ }^{\prime \prime}\right)$ equivocal reaction that cannot consistently be scored positive or negative; $+^{7}$, the superscript gives the day the reaction became positive; ND, not done.

${ }^{b}$ TSI, Triple sugar iron.

c Weak green color for all strains; see text.

${ }^{d}$ ONPG, $O$-nitrophenyl- $\beta$-D-galactopyranoside. 


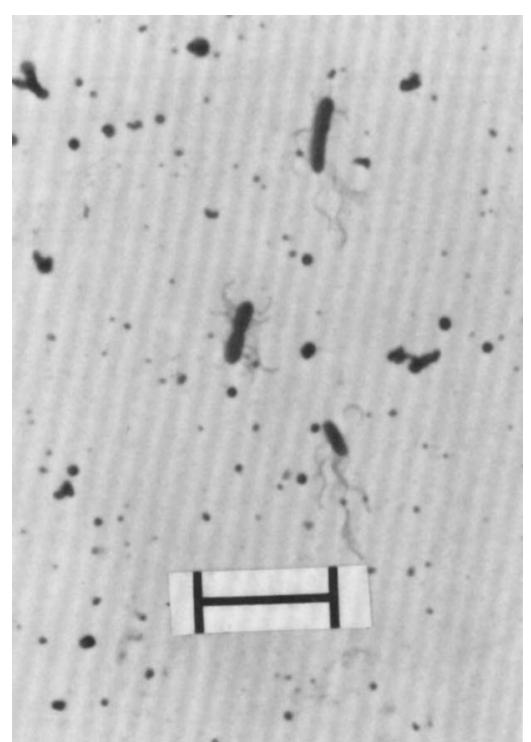

Fig. 2. Photomicrograph of the type strain (strain 1) of E. sakazakii showing cell size, morphology, and arrangement of flagella (the bar represents a distance of $10 \mu \mathrm{m})$.
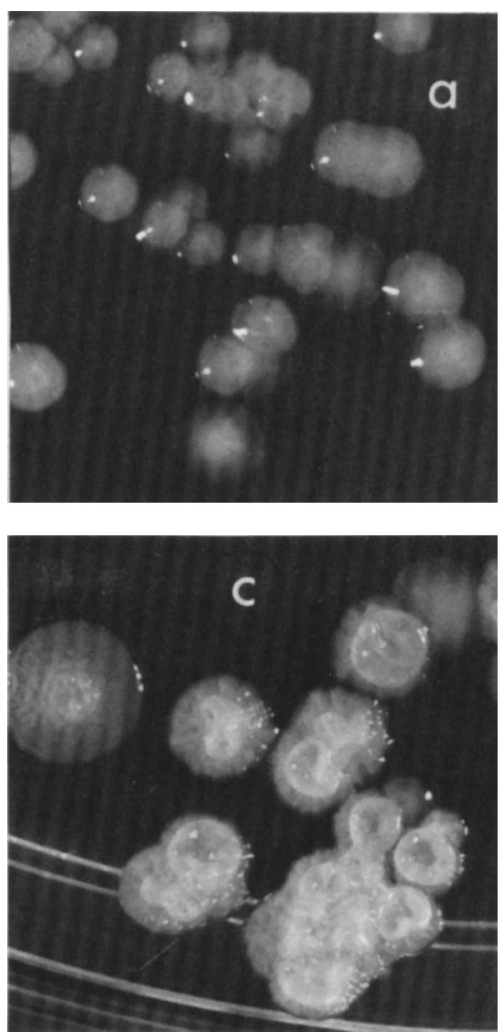

Biogroups. There were 14 combinations of the nine variable tests (Table 2, with the test for phenylalanine excluded). The combinations were defined as 14 biogroups in the species $E$. sakazakii (Table 3). The biogroups of the individual strains are listed in Table 1 . Biogroup 1 (the wild type) was by far the most common. The rarer biogroups (numbers 2 to 15 ) should be helpful in differentiating strains of $E$. saka$z a k i i$ in ecological or epidemiological studies.

Antibiotic susceptibility: disk method. Table 4 gives the inhibition zone sizes for 30 strains and the mean and standard deviations for each antibiotic. Antibiotic resistance was uncommon; only one strain (out of over 100 now tested) was multiply resistant. Strain 5 was highly resistant (no zone of inhibition around the disks) to streptomycin, kanamycin, tetracycline, and chloramphenicol. Figure 5 illustrates the difference in inhibition zone sizes between E. sakazakii strain 37 and $E$. cloacae strain 9023-77 against ampicillin and cephalothin. Figure 6 gives the zone size differences between many $E$. sakazakii and $E$. cloacae strains for the same drugs. This noticeable difference should prove useful in recognizing strains of $E$.
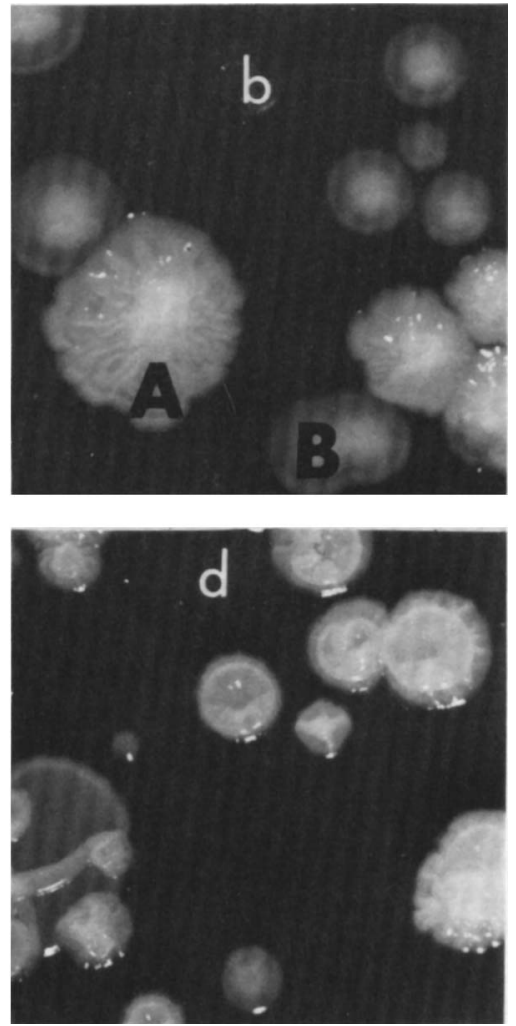

Fic. 3. Differences in colonial morphology (Trypticase soy agar plate incubated for $48 h$ at $25^{\circ} \mathrm{C}$ ). The quadrants $a$ and $b$ are strains 38 and 33 , respectively; quadrants $c$ and $d$ are strain 41 . The colony labeled $A$ is $3 \mathrm{~mm}$ in diameter. 


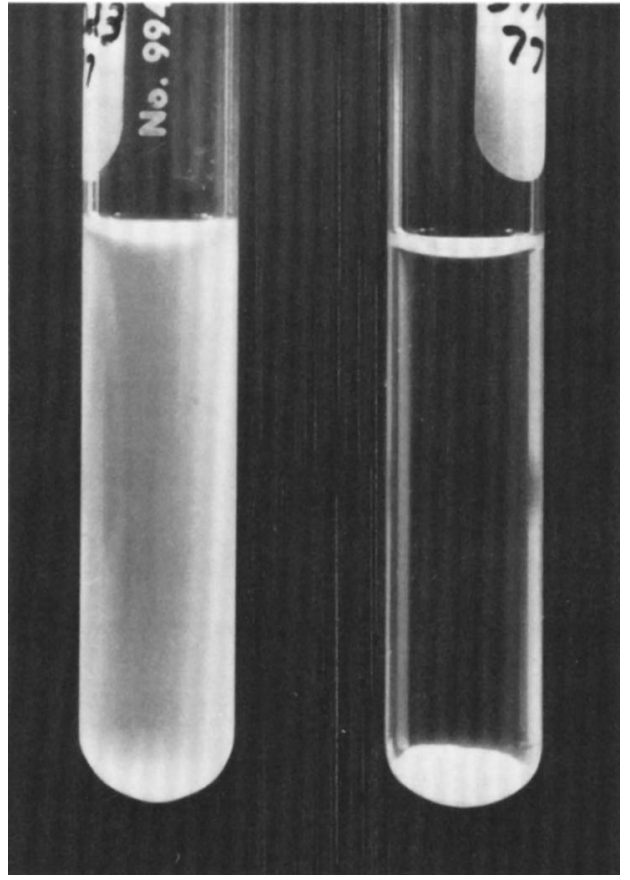

Fig. 4. Trypticase soy broth cultures $(24 \mathrm{~h}$ old $)$ of E. cloacae 9023-77 (left) and E. sakazakii 38, showing the large amount of sediment in the broth of $E$. sakazakii.

sakazakii. The antibiogram plate of strains which are biochemically identified as members of $E$. cloacae should be examined closely for yellow-pigment production (which is often obvious, even at $36^{\circ} \mathrm{C}$ ), and the inhibition zone sizes should be compared with those in Fig. 6 . Zones of $12 \mathrm{~mm}$ or greater for cephalothin and $18 \mathrm{~mm}$ or greater for ampicillin are indicative of E. sakazakii rather than $E$. cloacae.

Antibiotic susceptibility: MIC. Table 5 gives the MIC for 10 strains; these results are in good agreement with those obtained by the disk method. E. sakazakii was moderately susceptible to chloramphenical (MIC: 4 to $8 \mu \mathrm{g} / \mathrm{ml}$ ) and ampicillin (MIC: 2 to $4 \mu \mathrm{g} / \mathrm{ml}$ ), which are often used to treat patients with bacterial meningitis before culture and susceptibility results are available.

Growth on enteric plating media. Table 6 gives the plating efficiencies of the 57 strains of E. sakazakii on the different media. There was no inhibition on MacConkey, eosin methylene blue, or deoxycholate. The strains formed light to dark pink colonies with no precipitated bile around them. The colonies are quite distinct from the dark red colonies surrounded by precipitated bile, which is characteristic of $E$. coli. Because some of the colonies were light pink, $E$. sakazakii may be suspect as a lactose-negative
TABLE 3. Characteristics of the 15 biogroups recognized among the 57 strains of $E$. sakazakii studied

\begin{tabular}{|c|c|c|}
\hline $\begin{array}{l}\text { Biogroup } \\
\text { designation }\end{array}$ & $\begin{array}{c}\text { No. of } \\
\text { strains (\%) } \\
\text { in biogroup }\end{array}$ & Test differing from wild type \\
\hline $\begin{array}{l}1 \text { (Wild } \\
\text { type) }\end{array}$ & $24(42)$ & None \\
\hline 2 & $7(12)$ & Inositol $^{-}$ \\
\hline 3 & $5(9)$ & Motility $^{-}$ \\
\hline 4 & $4(7)$ & Ornithine $^{-}$ \\
\hline 5 & $3(5)$ & Malonate $^{+}$ \\
\hline 6 & $1(2)$ & Indole $\mathbf{e}^{+}$ \\
\hline 7 & $1(2)$ & $\mathrm{Gas}^{-}$ \\
\hline 8 & $1(2)$ & Nitrite $^{-}$ \\
\hline 9 & $3(5)$ & Inositol $^{-}$, malonate $^{+}$ \\
\hline 10 & $2(4)$ & Inositol $^{-}$, indole ${ }^{+}$ \\
\hline 11 & $1(2)$ & Inositol $^{-}$, dulcitol $^{+}$ \\
\hline 12 & $1(2)$ & Indole $^{+}$, malonate ${ }^{+}$ \\
\hline 13 & $1(2)$ & Methyl red ${ }^{+}$, Voges-Proskauer \\
\hline 14 & $1(2)$ & Inositol $^{-}$, malonate ${ }^{+}$, ornithine \\
\hline 15 & $2(4)$ & $\begin{array}{c}\text { Indole }^{+}, \text {malonate } \\
\alpha \text {-methyl glucoside } \\
\text {-melcitol }^{+}\end{array}$ \\
\hline
\end{tabular}

pathogen. About half of the strains formed either mucoid or leathery colonies on these media. On eosin methylene blue, only strain 24 produced the metallic sheen which is characteristic of $E$. coli. On tergitol 7 , there was no reduction in plating efficiency, and all of the strains had a yellow zone around them, indicating lactose fermentation. Colonies on XLD-3, XLD, and HE agars were also yellow (characteristic of a lactose fermenter like $E$. coli), but the plating efficiency was often reduced (Table 6). On bismuth sulfite (24-h-old plates), 14 strains were beginning to have the characteristic metallic sheen around the colony, which is typical of Salmonella. The sheen was even more pronounced at $48 \mathrm{~h}$. The 14 would probably be picked as suspect strains of Salmonella.

Lactose fermentation and the coliform concept. All of the strains except number 28 produced abundant gas (filling more than $50 \%$ of the insert tube) during the fermentation of $D$ glucose. Although all strains produced acid from lactose in enteric fermentation base, three did not form gas (Table 7). These same three strains also did not produce gas in lauryl tryptose broth and brilliant green bile broth. Surprisingly, only 40 strains produced gas in lactose broth. Thus, 70 to $95 \%$ (depending on the medium used) of the $E$. sakazakii strains would be coliforms on the basis of gas production from lactose at $35^{\circ} \mathrm{C}$. Thirty-three of the strains produced gas from lactose in EC medium at $44.5^{\circ} \mathrm{C}$, so $58 \%$ could be fecal coliforms on the basis of this criterion alone. None of our isolates came from water or sewage, but $E$. sakazakii can occur in human feces (isolate 29 was from a stool culture).

Habitat. Most E. sakazakii isolates have been from human clinical specimens. Four 
TABLE 4. Antibiotic susceptibility patterns ${ }^{\alpha}$ of 24 strains of E. sakazakii

\begin{tabular}{|c|c|c|c|c|}
\hline \multirow[b]{2}{*}{ Antibiotic } & \multicolumn{3}{|c|}{ Zone size (mm) } & \multirow{2}{*}{$\begin{array}{l}\text { \% of isolates } \\
\text { susceptible }\end{array}$} \\
\hline & Mean & $\begin{array}{l}\text { Standard } \\
\text { deviation }\end{array}$ & Range & \\
\hline Colistin $(10)^{b}$ & 11.6 & 1.4 & $8-14$ & 71 \\
\hline Nalidixic acid (30) & 21.8 & 2.1 & $18-28$ & 96 \\
\hline Sulfadiazine (250) & 18.7 & 3.6 & $12-24$ & 67 \\
\hline Gentamicin (10) & 20.8 & 2.3 & $16-26$ & 100 \\
\hline Streptomycin (10) & 18.0 & 2.4 & $14-22$ & 92 \\
\hline Kanamycin (30) & 21.0 & 1.4 & $20-24$ & 100 \\
\hline Tetracycline (30) & 20.3 & 1.2 & $18-22$ & 87 \\
\hline Chloramphenicol (30) & 23.4 & 2.1 & $22-30$ & 100 \\
\hline Penicillin (10 U) & 6.9 & 1.3 & $6-12$ & 0 \\
\hline Ampicillin (10) & 19.9 & 1.8 & $16-24$ & 100 \\
\hline Carbenicillin (100) & 25.4 & 2.3 & $22-30$ & 87 \\
\hline Cephalothin (30) & 12.9 & 2.2 & 8-18 & 13 \\
\hline
\end{tabular}

${ }^{a}$ Determined by the standardized single-disk method (Kirby-Bauer). The data for Fig. 6 were based on a different set of strains.

${ }^{b}$ Figures in parentheses are potencies of the disks in micrograms (or units if the number is followed by U).

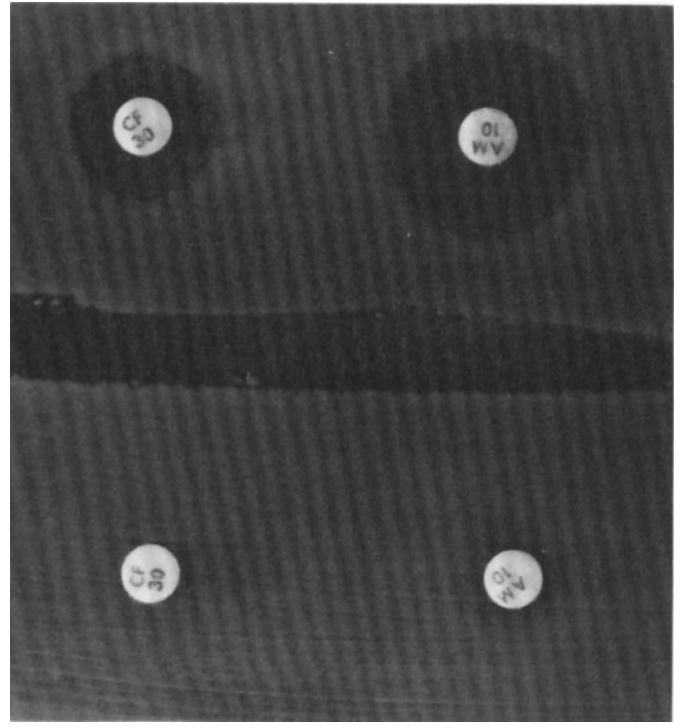

Fig. 5. Differentiation of E. sakazakii (top, strain 37) from $E$. cloacae (bottom, strain 9023-77) based on larger zones of inhibition around the cephalothin disk (left, marked CF 30) and ampicillin disk (right, marked AM 10).

(Table 1) were isolated from spinal fluid, and two were from blood. Three other common sites were the respiratory tract (sputum, 10 isolates; throat, 2 isolates; nose, 1 isolate), the intestines (stool or gut, 8 isolates), and skin or wounds (6 isolates). Other specimens included bone marrow (two isolates), eye (two isolates), ear (one isolate), and a breast abscess (1 isolate). One isolate was from food-a can of previously unopened dried milk. An important isolate (number 50) came from an uninoculated bottle of medium used in growing bacteria from blood cultures. This was clearly an instance of contamination

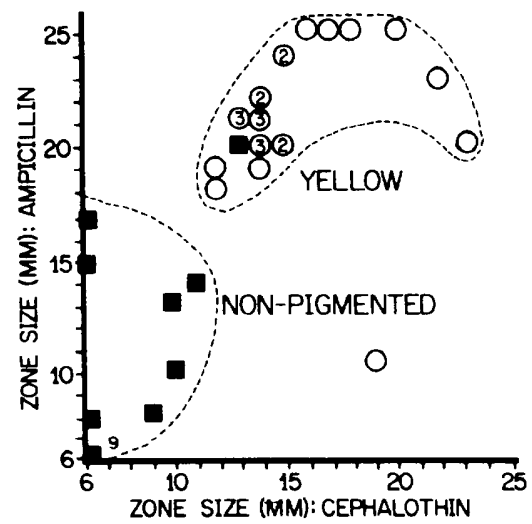

FIG. 6. Differentiation of E. sakazakii and E. cloacae by differences in zone sizes around the antibiotics cephalothin and ampicillin. Zone sizes for each strain are plotted; strains of E. sakazakii ("yellow") are represented by open circles and strains of $E$. cloacae ('nonpigmented") are represented by black squares. The number of strains with identical results is indicated inside the open circle or above and to the right of the black square.

and indicates that it is essential to distinguish isolates which actually come from clinical specimens from those which contaminate them. Isolate 50 probably would have been reported as causing a positive blood culture if the contaminated bottle had not been noticed.

Clinical significance. This organism is a documented $(20,27)$ cause of neonatal meningitis, and 4 of the 57 isolates in our series were from spinal fluid. It was usually difficult to show clinical significance for the other isolates because other bacterial species were also present in the specimens. Based on data submitted by the Enterobacteriaceae Study Group, we concluded the E. sakazakii is probably only a col- 
TABLE 5. MICs of 12 antibiotics against 10 strains of E. sakazakii

\begin{tabular}{|c|c|c|c|c|c|c|c|c|c|c|c|}
\hline \multirow{2}{*}{ Antibiotic } & \multicolumn{11}{|c|}{ Cumulative $\%$ of strains inhibited at an antibiotic concn $(\mu \mathrm{g} / \mathrm{ml})$ of: } \\
\hline & 0.25 & 0.5 & 1 & 2 & 4 & 8 & 16 & 32 & 64 & 128 & 256 \\
\hline Ampicillin & & & & 60 & 100 & & & & & & \\
\hline Carbenicillin & & & & & & 70 & 100 & & & & \\
\hline Cephalothin & & & & & & & & 70 & 100 & & \\
\hline Amikacin & & & 100 & & & & & & & & \\
\hline Gentamicin & 30 & 100 & & & & & & & & & \\
\hline Kanamycin & & & 60 & 100 & & & & & & & \\
\hline Tobramycin & 10 & 100 & & & & & & & & & \\
\hline Chloramphenicol & & & & & 40 & 100 & & & & & \\
\hline Sulfisoxazole & & & & & & & & 40 & 80 & 100 & \\
\hline Tetracycline & & & 10 & 90 & 100 & & & & & & \\
\hline Nalidixic acid & & & & & 70 & 100 & & & & & \\
\hline Nitrofurantoin & & & & & & 10 & 70 & 100 & & & \\
\hline Trimethoprim-sulfa & $100^{a}$ & & & & & & & & & & \\
\hline
\end{tabular}

${ }^{a}$ All strains were inhibited at the lowest concentration $(0.25 \mu \mathrm{g}$ of trimethoprim-4.75 $\mu \mathrm{g}$ of sulfamethoxazole per $\mathrm{ml})$.

TABLE 6. Growth of 57 strains of E. sakazakii on plating media commonly used in enteric bacteriology

\begin{tabular}{lrrrrr}
\hline & \multicolumn{5}{c}{ \% of 57 strains whose plating efficiency ${ }^{b}$ was reduced by: } \\
\cline { 2 - 5 } & $0 \%$ & $1-90 \%$ & $90-99 \%$ & $99-99.9 \%$ & $>99.9 \%$ \\
\hline MacConkey & 100 & & & & \\
EMB $^{c}$ & 100 & & & & \\
Desoxycholate $^{a}$ & 100 & & & & 19 \\
Tergitol 7 & 100 & & 5 & 16 & 16 \\
XLD-3 additions & 91 & 4 & 23 & 12 & 44 \\
XLD & 40 & 2 & 7 & 14 & 91 \\
Hektoen & 61 & 4 & 16 & 0 & 100 \\
Bismuth sulfite & 25 & 2 & 5 & 0 & \\
Brilliant green & 2 & 0 & 0 & & \\
TCBS & 0 & 0 & & & \\
\hline
\end{tabular}

${ }^{a}$ The media were poured one day, refrigerated overnight, and then used the next day.

${ }^{b}$ Plating efficiency is defined as the number of colonies growing on the test medium divided by the number growing on Trypticase soy agar at the same dilution. Example: if at a $10^{-3}$ dilution there were 160 colonies on Trypticase soy agar and 5 on XLD, the plating efficiency would be $5 / 160$ or 0.031 (a reduction of $97 \%$ ); this strain would then fall in the range of $90-99 \%$ reduction.

${ }^{c}$ EMB, Eosin methylene blue.

TABLE 7. Gas formation by 57 strains of E. sakazakii during lactose fermentation in different media used to define coliform and fecal coliform organisms

\begin{tabular}{|c|c|c|c|}
\hline \multirow{2}{*}{ Medium } & \multirow{2}{*}{$\begin{array}{l}\text { Incubation temp } \\
\qquad\left({ }^{\circ} \mathrm{C}\right)\end{array}$} & \multicolumn{2}{|c|}{$\begin{array}{c}\text { Cumulative no. }(\%) \text { of strains with visible ga } \\
\text { at: }\end{array}$} \\
\hline & & $24 \mathrm{~h}$ & $48 \mathrm{~h}$ \\
\hline Enteric standard (from Table 2) & 35 & $22(39)$ & $54(95)$ \\
\hline Lactose broth & 35 & $24(42)$ & $40(70)$ \\
\hline Lauryl tryptose broth & 35 & $32(56)$ & $54(95)$ \\
\hline Brilliant green bile broth ${ }^{a}$ & 35 & $31(54)$ & $54(95)$ \\
\hline Enteric base-lactose & 44.5 & $6(11)$ & $22(39)$ \\
\hline $\mathrm{EC}^{a}$ & 44.5 & $11(19)$ & $33(58)$ \\
\hline
\end{tabular}

\footnotetext{
${ }^{a}$ Inoculated from a 48-h-old lauryl tryptose broth culture.
}

onizer at these sites, which contain a mixed flora. It was probably not clinically significant.

Isolate 54 was from a physician's stethescope, so a cross-infection mechanism was immediately apparent. However, E. sakazakii was rarely isolated in the participating clinical microbiology laboratories (none to three isolates per year per lab), and the isolates have been well separated by time and space. The one exception was a hospital that had 29 patients with $E$. sakazakii respiratory tract colonization (and some other colonizations) during a 7 -month period. No other clusters of infection have been reported by the 39 hospitals. 


\section{DISCUSSION}

The first objective of this study was to confirm that the organism known as "yellow-pigmented Enterobacter cloacae" is a new species and not a biogroup of $E$. cloacae. We are convinced that this is the case, and we have thus proposed the name Enterobacter sakazakii for this new species. Strains of E. sakazakii were 83 to $91 \%$ related to each other by DNA-DNA hybridization but were only 31 to $54 \%$ related to $E$. cloacae (Table 8). Once this was established, phenotypic differences besides that of yellow pigment were found between the two species. Phenotypic differences between $E$. sakazakii and some other species in the family "Enterobacteriaceae" are summarized in Table 9. A strain which has been identified as Enterobacter cloacae should be checked for yellow pigment production, D-sorbitol fermentation, and a delayed-positive DNase test. An alternative approach is to check the zones of inhibition around cephalothin and ampicillin and compare the re- sults to those given in Table 4 or Fig. 6. Keen observation rather than sophisticated testing is required to isolate and identify this new species. The distinctive colony morphology, color, and consistency (Fig. 3) should also prove useful, but it must be remembered that smooth, nondistinct colonies are produced, after storage, from distinct colonies. Strains with only this nondistinct colony type may exist in nature also. Yellow pigment production is strong at $25^{\circ} \mathrm{C}$, but is often weak at $36^{\circ} \mathrm{C}$, so this differential criterion should not be used alone.

The question of whether the organism under discussion is a "biogroup" of an already known species or a "new species" was easily answered in favor of the latter, but it raised a more difficult question: what genus is best for the new species? We have argued $(8,9)$ that a species should be generically assigned on the basis of evolutionary relatedness rather than superficial phenotypic similarity (such as the ability to form endospores, which can be shared by distinct evolutionary lines). One criterion for assigning species

TABLE 8. Relatedness by DNA-DNA hybridization of E. sakazakii to other members of the family "Enterobacteriaceae"

\begin{tabular}{lll}
\hline \multicolumn{1}{c}{ Species } & \multicolumn{2}{c}{ \% Related to: } \\
\cline { 2 - 3 } & & \multicolumn{1}{c}{$\begin{array}{c}\text { E. sakazakii 1 } \\
\text { (type strain) }\end{array}$} \\
\hline Enterobacter sakazakii & $89^{a}(2 ; 87-91)^{b}$ & $86(5 ; 83-89)$ \\
Enterobacter cloacae & $51(5 ; 47-54)$ & $39(9 ; 31-49)$ \\
Enterobacter aerogenes & $44(1)$ & $34(1)$ \\
Enterobacter agglomerans & $38(3 ; 36-40)$ & $36(2 ; 29-34)$ \\
Citrobacter diversus & $51(2 ; 48-53)$ & ND \\
"Citrobacter amalonaticus" & $51(1)$ & ND \\
Citrobacter freundii & $41(1)$ & ND \\
Klebsiella pneumoniae & $45(1)$ & $39(1)$ \\
Escherichia coli & $43(1)$ & $33(1)$ \\
Salmonella typhimurium & $41(1)$ & $33(1)$ \\
Serratia marcescens & $39(1)$ & ND \\
Hafnia alvei & $30(1)$ & ND \\
Erwinia amylovora & $30(1)$ & ND \\
Erwinia carotovora & $28(1)$ & ND \\
\hline
\end{tabular}

${ }^{a}$ Arithmetic means of all strains tested. ND, Not determined.

${ }^{b}$ The first number in parentheses is the number of strains tested; the range of values follows the comma.

TABLE 9. Biochemical tests for differentiating E. sakazakii from related taxa in Enterobacter and Hafnia

\begin{tabular}{lccccccc}
\hline \multicolumn{1}{c}{ Test } & \multicolumn{1}{c}{ \%of strains positive } \\
\cline { 2 - 8 } & $\begin{array}{c}\text { E. saka- } \\
\text { zakii }\end{array}$ & E. cloacae & $\begin{array}{c}\text { E. aero- } \\
\text { genes }\end{array}$ & $\begin{array}{c}\text { E. agglom- } \\
\text { erans }\end{array}$ & H. alvei & $\begin{array}{c}\text { "E. gergo- } \\
\text { viae" }\end{array}$ & $\begin{array}{c}\text { Enteric } \\
\text { group 1 }\end{array}$ \\
\hline Yellow pigment $\left(25^{\circ} \mathrm{C}\right)$ & $99^{a}$ & 1 & 1 & 80 & 1 & 1 & 50 \\
DNase (7 days) & 99 & 1 & 1 & 1 & 1 & 1 & 1 \\
Lysine decarboxylase & 1 & 1 & 99 & 1 & 99 & 64 & 90 \\
Arginine dihydrolyase & 96 & 97 & 1 & 1 & 9 & 1 & 40 \\
Ornithine decarboxylase & 91 & 96 & 99 & 1 & 99 & 99 & 1 \\
D-Sorbitol (acid) & 1 & 95 & 99 & 24 & 1 & 1 & 1 \\
\hline
\end{tabular}

${ }^{a}$ Percent of strains positive for the taxon after $48 \mathrm{~h}$ of incubation (except for DNase, which is 7 days) at $36^{\circ} \mathrm{C}$ (except yellow pigment, which is $25^{\circ} \mathrm{C}$ ). The upper and lower values have been set arbitrarily at 99 and 1 rather than at 100 and 0 . 
to the same genus is a closer relatedness by DNA-DNA hybridization. Members of the same genus should be closer to each than to species in other genera. This concept was fully developed in our argument to divide the genus Proteus, which is a very "good" genus if only phenotypic similarity is considered, into Proteus, Providencia, and Morganella (8). This same criterion is now being used with other microbial groups for assigning new species to a genus and for redefining existing genera. Based on DNA-DNA hybridization, there is no clear generic assignment for $E$. sakazakii because it is $\mathbf{5 3}$ to $54 \%$ related to species in two different genera, Enterobacter and Citrobacter (Table 8). A choice is more evident, however, when its relationships with only the type species of these genera are considered. E. sakazakii strain 27 was only $41 \%$ related to the type species of Citrobacter, $C$. freundii; but it was $51 \%$ related to the type species of Enterobacter, E. cloacae. On the basis of this closer relatedness by DNA-DNA hybridization and closer phenotypic similarity to Enterobacter cloacae than to Citrobacter freundii, we believe that Enterobacter is the most logical assignment for E. sakazakii at present. If closer evolutionary relatives to $E$. sakazakii are found, it will be logical, on the basis of such knowledge, to form a new genus or transfer it to a different genus. One good possibility is to study the group of strains (we now have four) referred to as $E$. sakazakii biogroup 15. These strains share most of the properties of the species, but they are dulcitol-positive and $\alpha$-methyl-glucoside-negative, characteristics not found in other strains of the species. Biogroup 15 is also indole-positive and malonate-positive, a combination found in only one other strain. None of the biogroup 15 strains was included in the DNA-DNA hybridization studies, but we suspect that the phenotypic differences may reflect evolutionary divergence which could be detected by this technique. If this is the case, then it may be desirable to form a new genus, with $E$. sakazakii biogroups 1 to 14 and $E$. sakazakii biogroup 15 forming two species. This hypothesis should be tested. In the meantime, the new species should remain in Enterobacter, which is becoming a heterogeneous genus anyway. E. sakazakii has some phenotypic similarity to Erwinia, but it is only $30 \%$ related by DNA-DNA hybridization to $E r$ winia amylovora, the type species for the genus. E. sakazakii strains are positive for arginine dihydrolase and ornithine decarboxylase, grow at $45^{\circ} \mathrm{C}$, and do not liquefy pectin, so it would be difficult to fit the new species into the $E r$ winia amylovora-E. herbicola-E. carotovora group as currently defined (12). Erwinia, however, is a heterogenous genus, and some of the named or unnamed groups may be related to $E$. sakazakii. In the future, there will probably be many taxonomic changes in Erwinia, Enterobacter, and the "Enterobacter agglomerans complex." Many new genera will probably be formed, and we suspect that $E$. sakazakii may logically be included in one of them.

Although strains now known to be members of $E$. sakazakii were first described in 1961, we know very little about this species' distribution, reservoirs in nature, ecology, or epidemiology. The Enterobacteriaceae Study Group was formed to try to answer this type of question in relation to the entire family. Over 100 strains of $E$. sakazakii have now been isolated, and the results confirm that $E$. sakazakii is rarely encountered in clinical specimens; some laboratories have not isolated it in 2 years. Occasionally, however, as noted earlier, it causes life-threatening neonatal meningitis. All 24 strains cited in Table 4 were susceptible in vitro to chloramphenicol and ampicillin, so conventional antibiotic treatment for bacterial meningitis may be effective for $E$. sakazakii also.

Some microbiologists, particularly clinical microbiologists, have questioned the wisdom of describing new species. They fail to realize that the first step in understanding any entitywhether it is an organism, observation, event, or phenomenon-is to name and describe that entity. There is nothing wrong with the vernacular name "yellow-pigmented Enterobacter cloacae;" however, we are convinced that an organism is seldom fully understood or fully appreciated until it is given a scientific name. Up to the present, very little has been written about "yellow-pigmented $E$. cloacae." We hope this situation will change now that the organism has been given a scientific name. We know, from letters and telephone conversations, that information is forthcoming which will add considerably to our understanding of this new species.

\section{ACKNOWLEDGMENTS}

We thank Manley Mandel for doing the G+C determinations, W. A. Clark for doing the flagella strains, and S. P. Lapage and B. Holmes for furnishing the NCTC cultures. Members of the Enterobacteriaceae Study Group who participated in this study are as follows: Daniel Amsterdam, Kingsbrook Jewish Medical Center, Brooklyn, N.Y.; Donald Armstrong, Sloan Kettering Cancer Center, New York, N.Y.; Herman Baer, Hospital, University of Florida, Gainesville, Fla.; Donna J. Blazevic, University of Minnesota Hospitals, Minneapolis, Minn.; Raymond A. Bobo, University of Alabama in Birmingham, Birmingham, Ala.; Edward J. Bottone, Mount Sinai Hospital, New York, N.Y.; Elizabeth Butt, Georgia Department of Human Resources, Atlanta, Ga.; Timothy J. Cleary, Jackson Memorial Hospital, Miami, Fla.; R. R. Colwell and James Kaper, University of Maryland, College Park, Md.; Richard F. D'Amato, API, Plainville, N.Y.; Timothy Dolan, St. Mary Medical Center, Gary, Ind.; B. J. Dutka, Canada Centre for Inland Waters, Burlington, Ontario, Canada; Paul D. Ellner, Columbia Presbyterian Medical Center, New York, N.Y.; Thomas L. Gavan, Cleveland Clinic Foundation, Cleveland, Ohio; Edwin E. Geldreich, Environmental Protection 
Agency, Cincinnati, Ohio; E. H. Gerlach, St. Francis Hospital, Wichita, Kans.; Dieter Groschel, M. D. Anderson Hospital, Houston, Tex.; Ian Holder, Shriners Hospitals-Burns Institute, Cincinnati, Ohio; Keith Hadley, San Francisco General Hospital, San Francisco, Calif.; Henry Isenberg, Long Island Jewish Hillside Medical Center, New Hyde Park, N.Y.; Dolph Klein, Duke University Medical Center, Durham, N.C.; Phyllis Kuhn, Hamot Medical Center, Erie, Pa.; Lawrence J. Kunz, Massachusetts General Hospital, Boston, Mass.; Hermy Lior, Laboratory Centre for Disease Control, Ottawa, Ontario, Canada; James D. MacLowry, National Institutes of Health, Bethesda, Md.; William J. Martin, UCLA Hospital Center for the Health Sciences, Los Angeles, Calif.; John M. Matsen, University of Utah Medical Center, Salt Lake City, Utah; Laurence R. McCarthy, North Carolina Memorial Hospital, Chapel Hill, N.C.; James C. McLaughlin, Hartford Hospital, Hartford, Conn.; Josephine A. Morello, University of Chicago Hospitals, Chicago, Ill.; Erwin Neter, Buffalo Children's Hospital, Buffalo, N.Y.; Fred Philipp, Shadyside Hospital, Pittsburgh, Pa.; Helen M. Pollock and Marie B. Coyle, Harborview Medical Center, Seattle, Wash.; Richard K. Porschen, VA Hospital, Long Beach, Calif.; Catherine Powers, California State Health Department, Berkeley, Calif.; Sally Jo Rubin, St. Francis Hospital, Hartford, Conn.; Minnie Schreiber, Microbiology Laboratory, Florida State Health Department, Jacksonville, Fla.; J. E. Seals, Enteric Disease Branch, Center for Disease Control, Atlanta, Ga.; Irving J. Slotnick, CedarsSinai Medical Center, Los Angeles, Calif.; Alex C. Sonnenwirth, Jewish Hospital of St. Louis, St. Louis, Mo.; Mortimer P. Starr, University of California, Davis, Calif.; M. J. Surgalla, Roswell Park Memorial Institute, Buffalo, N.Y.; Welton Taylor, Chicago, III.; T. J. Trust, University of Victoria, Victoria, British Columbia, Canada; Alexander Von Graevenitz, YaleNew Haven Hospital, New Haven, Conn.; John A. Washington, Mayo Clinic, Rochester, Minn.; Viola Mae Young, Baltimore Cancer Research Center, Baltimore, Md.; and Ronald J. Zabransky, Mount Sinai Medieal Center, Milwaukee, Wis.

\section{REPRINT REQUESTS}

Address reprint requests to: Center for Disease Control, Attn: J. J. Farmer III, Building 1, Room B341 Center for Disease Control, Atlanta, Ga. 30333 .

\section{LTTERATURE CITED}

1. American Public Health Association. 1975. Standard Methods for the Examination of Water and Wastewater, 14th American Public Health Association, Inc., New York.

2. Bauer, A. W., W. M. M. Kirby, J. Sherris, and M. Turk. 1966. Antibiotic susceptibility testing by a standardized single disk method. Am. J. Clin. Pathol. 45: 493-496.

3. Berns, K. I., and C. A. Thomas. 1965. Isolation of high molecular weight DNA from Hemophilus influenzae. J. Mol. Biol. 11:476-490.

4. Brenner, D. J. 1974. DNA reassociation for the clinical differentiation of enteric bacteria. Public Health Lab. 32:118-130.

5. Brenner, D. J. 1979. Speciation in Yersinia. Contr. Microbiol. Immunol. 5:990-999.

6. Brenner, D. J., G. R. Fanning, K. E. Johnson, R. V. Citarella, and S. Falkow. 1969. Polynucleotide sequence relationships among members of Enterobacteriaceae. J. Bacteriol. 98:637-650.

7. Brenner, D. J., G. R. Fanning, G. V. Miklos, and A. G. Steigerwalt. 1973. Polynucleotide sequence relatedness among Shigella species. Int. J. Syst. Bacteriol. 23:1-7.
8. Brenner, D. J., J. J. Farmer III, G. R. Fanning, A. G. Steigerwalt, P. Klykken, H. G. Wathen, F. W. Hickman, and W. H. Ewing. 1978. Deoxyribonucleic acid relatedness of Proteus and Providencia species. Int. J. Syst. Bacteriol. 28:269-282.

9. Brenner, D. J., J. J. Framer III, F. W. Hickman, M. A. Asbury, and A. G. Steigerwalt. 1977. Taxonomic and nomenclature changes in Enterobacteriaceae. Center for Disease Control, Atlanta, Ga.

10. Brenner, D. J., C. Richard, A. G. Steigerwalt, M. A. Asbury, and M. Mandel. 1980. Enterobacter gergoviae sp. nov.: a new species of Enterobacteriaceae found in clinical specimens and the environment. Int. J. Syst. Bacteriol. 30:1-6.

11. Brenner, D. J., A. G. Steigerwalt, and G. R. Fanning. 1972. Differentiation of Enterobacter aerogenes from klebsiellae by deoxyribonucleic acid reassociation. Int. J. Syst. Bacteriol. 22:193-200.

12. Buchanan, R. E., and W. E. Gibbons. 1974. Bergey's manual of determinative bacteriology, 8 th ed. Williams and Wilkins Co., Baltimore.

13. Clark, W. A. 1976. A simplified Leifson flagella stain. J. Clin. Microbiol. 3:632-634.

14. Edwards, P. R., and W. H. Ewing. 1972. Identification of Enterobacteriaceae, 3rd ed. Burgess Publishing Co., Minneapolis.

15. Farmer, J. J., III. 1978. Standardization and automation in biotyping, p. 68-97. In A. Balows and H. D. Isenberg (ed.), Biotyping in the clinical microbiology laboratory. Charles C Thomas, Publisher, Springfield, Ill.

16. Farmer, J. J., III, F. W. Hickman, and J. V. Sikes. 1975. Automation of Salmonella typhi phage typing. Lancet ii:787-790.

17. Gilardi, G. L., and E. Bottone. 1971. Erwinia and yellow-pigmented Enterobacter isolates from human sources. Antonie van Leeuwenhoek. J. Microbiol. Serol. $37: 529-535$.

18. Hickman, F. W., and J. J. Farmer III. 1978. Salmonella typhi: identification, antibiograms, serology and bacteriophage typing. Am. J. Med. Technol. 44:1149-1159.

19. Jain, K., K. Radsak, and W. Mannheim. 1974. Differentiation of the Oxytocum group from Klebsiella by deoxyribonucleic acid-deoxyribonucleic acid hybridization. Int. J. Syst. Bacteriol. 24:402-407.

20. Jøker, R. N., T. Nørholm, and K. E. Siboni. 1965. A case of neonatal meningitis caused by yellow Enterobacter. Danish Med. Bull. 12:128-130.

21. Marmur, J., S. Falkow, and M. Mandel. 1963. New approaches to bacterial taxonomy. Annu. Rev. Microbiol. 17:329-372.

22. Negut, M., and G. Hermann. 1975. A comparison of two methods for detecting beta-D-galactosidase. Public Health Lab. 33:190-193.

23. Richard, C., B. Joly, J. Sirot, G. H. Stoleru, and M. Popoff. 1976. Etude de souches de Enterobacter appartenant à un groupe particulier proche de $E$. aero genes. Ann. Microbiol. (Inst. Pasteur) 127 A:545-548.

24. Skerman, V. B. D., V. McGowan, and P. H. A. Sneath (ed.). 1980. Approved lists of bacterial names. Int. J. Syst. Bacteriol. 30:225-420.

25. Society of American Bacteriologists. 1957. Manual of microbiological methods. McGraw Hill Book Co., New York.

26. Steigerwalt, A. G., G. R. Fanning, M. A. Fife-Asbury and D. J. Brenner. 1976. DNA relatedness among species of Enterobacter and Serratia. Can. J. Microbiol. 22:121-137.

27. Urmenyi, A. M. C., and A. W. Franklin. 1961. Neonatal death from pigmented coliform infection. Lancet i:313315. 